\title{
Structure and Electronic Configuration of an Iron(II) Complex in a LIESST State: A Pump and Probe Method
}

\author{
Chou-Fu Sheu, ${ }^{[a]}$ Kowa Chen, ${ }^{[a]}$ Szu-Miao Chen, ${ }^{[a]}$ Yuh-Sheng Wen, ${ }^{[a]}$ \\ Gene-Hsiang Lee, ${ }^{[a]}$ Jin-Ming Chen, ${ }^{[b]}$ Jyh-Fu Lee, ${ }^{[b]}$ Bing-Ming Cheng, ${ }^{[b]}$ \\ Hwo-Shuenn Sheu, ${ }^{[b]}$ Nobuhiro Yasuda, ${ }^{[c]}$ Yoshiki Ozawa, ${ }^{[d]}$ Koshiro Toriumi, ${ }^{[d]}$ and \\ Yu Wang*[a]
}

\begin{abstract}
Two polymorphs of mononuclear six-coordinate iron(II) spin-crossover complex trans-[Fe(tzpy $\left.)_{2}(\mathrm{NCS})_{2}\right]$ (tzpy =3-(2-pyridyl)[1,2,3]triazolo[1,5a]pyridine) (1) were isolated and structurally characterized. According to the thermally dependent magnetic measurements, polymorph A undergoes a gradual spin transition from a paramagnetic high-spin state $\left({ }^{5} \mathrm{~T}_{2}, S=2\right.$, HS-1) above $200 \mathrm{~K}$ to a diamagnetic low-spin state $\left({ }^{1} \mathrm{~A}_{1}, S=0\right.$, LS- 1$)$ below $120 \mathrm{~K}$, whereas polymorph $\mathbf{B}$ shows an abrupt spin transition with $T_{1 / 2}$ at $102 \mathrm{~K}$. Molecular and crystal structures of polymorph $\mathbf{A}$ in the HS-1 and LS-1 states were studied at 300 and $40 \mathrm{~K}$, respectively. Significant differences in $\mathrm{Fe}-\mathrm{N}$ distances and coordination geometries of $\mathrm{Fe}$ were found between the
\end{abstract}

two spin states, as expected. Light-induced excited spin state trapping (LIESST) was observed upon irradiating the crystal with $532 \mathrm{~nm}$ laser light at $40 \mathrm{~K}$, whereupon a metastable highspin state (HS-2) was formed; the molecular and crystal structure of this metastable state were investigated by a pump and probe method because of its relatively fast relaxation. The electronic configuration of the Fe center in the HS-1, LS-1, and LIESST (HS-2) states were further confirmed by $\mathrm{Fe} \mathrm{K}$ - and L-edge absorption spectroscopy. In ad-

Keywords: iron - LIESST (lightinduced excited spin-state trapping) - magnetic properties $\cdot$ spin crossover $\cdot$ structure elucidation dition, the $\mathrm{C} \equiv \mathrm{N}$ stretching frequency on the ligand can also be followed through the spin transition. The excitation and relaxation process concerning such metastable state were followed by the $\mathrm{C} \equiv \mathrm{N}$ stretching frequency and magnetic susceptibility measurements in the temperature ranges $15-55 \mathrm{~K}$ and $5-$ $80 \mathrm{~K}$, respectively. The structure and electronic configuration of the LIESST state of polymorph A were firmly established by X-ray diffraction, X-ray absorption, infrared absorption, and magnetic measurements. A single-crystal-to-single-crystal transition through irradiation was demonstrated. The changes in structure and electronic configuration as a result of the spin transition are believed to occur concurrently.

\section{Introduction}

[a] Dr. C.-F. Sheu, K. Chen, S.-M. Chen, Y.-S. Wen, Dr. G.-H. Lee, Prof. Y. Wang

Department of Chemistry, National Taiwan University

No. 1, Sec. 4, Roosevelt Road, Taipei, Taiwan 106

Fax: $(+886) 2-23638377$

E-mail: wangyu@ntu.edu.tw

[b] Dr. J.-M. Chen, Dr. J.-F. Lee, Dr. B.-M. Cheng, Dr. H.-S. Sheu National Synchrotron Radiation Research Center 101 Hsin-Ann Road, Hsinchu Science Park Hsinchu 30076, Taiwan

[c] Dr. N. Yasuda Japan Synchrotron Radiation Research Institute (JASRI) 1-1-1 Kouto, Sayo-cho, Sayo-gun, Hyogo 679-5198 (Japan)

[d] Prof. Y. Ozawa, Prof. K. Toriumi

Graduate School of Material Science, University of Hyogo 3-2-1 Kouto, Kamigori-cho, Ako-gun, Hyogo 678-1297 (Japan)

It is known that many six-coordinate iron(II) complexes exhibit a spin transition (ST) when subjected to external perturbations such as temperature, pressure, light irradiation, or the inclusion or exclusion of solvent molecules. ${ }^{[1]}$ This ST is often accompanied by physical property changes in magnetism, color, or dielectric constant, which makes it feasible for future applications such as molecular memory, molecular switches, molecular sensors, data storage, and display devices. $^{[2]}$ The light-induced excited spin state trapping (LIESST) $^{[3]}$ phenomenon is commonly observed in iron(II) spin-crossover (SCO) complexes at extremely low temperature by using laser light with appropriate wavelength as a pumping source. In addition, much effort has been devoted 
to the synthesis of new molecule-based multifunctional materials, ${ }^{[2 a, 4]}$ in which the SCO properties may be incorporated with other useful properties, such as liquid crystallinity, ${ }^{[5]}$ electrical conductivity, ${ }^{[6]}$ and nonlinear optics. ${ }^{[2 a, 7]}$

The structure at the metastable (LIESST) state is the center of interest, as it may provide significant information concerning the structural change during the excitation and the relaxation process, which can then be directly correlated with the change in electronic configuration of the iron(II) ion. However, the difficulty of measuring a single-crystal structure at a metastable state has prevented rapid progress; to our knowledge, only a handful of structures at a LIESST state have been determined ${ }^{[8]}$ so far. Recently, Marchivie et al. surveyed the literature on the $\left[\mathrm{Fe}^{\mathrm{II}} \mathrm{L}_{n}(\mathrm{NCS})_{2}\right]$ series of complexes and found that a linear correlation exists between the $T$ (LIESST) value, the critical temperature for which the light-induced information was erased, and the distortion of the metal coordination sphere. ${ }^{[9]}$ However, this result is based on only a limited number of structures at the metastable state. More structural information at the LIESST state is still needed to understand fully the relationship between the changes in electronic configuration and changes in geometry. ${ }^{[10]}$

Different magnetic properties arise from various polymorphs of SCO complexes, ${ }^{[11]}$ slight differences in intramolecular conformation or intermolecular interactions such as hydrogen bonding or $\pi-\pi$ stacking could induce a significant shift in transition temperature. ${ }^{[12]}$ Typical examples such as in $\left[\mathrm{FeL}_{2}(\mathrm{NCX})_{2}\right] \quad\left(\mathrm{L}=\left(N-2^{\prime}\right.\right.$-pyridylmethylene $)$-4-(aminobiphenyl) (PM-BiA), $X=S ; ;^{[13]} \mathrm{L}=2,2^{\prime}$-bi-2-thiazoline (bt), $\mathrm{X}=\mathrm{S} ;{ }^{[14]} \mathrm{L}=4,6$-bis $\left(2^{\prime}, 2^{\prime \prime}\right.$-pyridyl)pyrazine (dppt), $\mathrm{X}=\mathrm{S} ;{ }^{[15]}$ or $\mathrm{L}=4$-amino-3,5-bis(pyridin-2-yl)-1,2,4-triazole (abpt), $\mathrm{X}=\mathrm{S}, \mathrm{Se},{ }^{[16]}$ or tcnoet $=1,1,3,3$-tetracyano-2-ethoxypropenide $\left.{ }^{[17]}\right)$ and others such as $\left[\mathrm{Fe}\left\{\left(p-\mathrm{IC}_{6} \mathrm{H}_{4}\right) \mathrm{B}(3-\mathrm{Mepz})_{3}\right\}_{2}\right]^{[18]}$ (3$\mathrm{Mepz}=3$-methylpyrazolyl) and [Fe\{(3-aminopropyl)bis(2pyridylmethyl)amine $\left.(\mathrm{NCS})_{2}\right]^{[19]}$ all exhibit quite different behavior in various forms of polymorphs. Recently the SCO Fe complex trans-[Fe $\left.(\mathrm{abpt})_{2}\left(\mathrm{~N}(\mathrm{CN})_{2}\right)_{2}\right]^{[20]}$ was also found to have different polymorphs; therefore, detailed structural analysis becomes essential to understand the magnetic behavior.

The inclusion or exclusion of solvent molecules in the lattice of SCO complexes often yields the different magnetic behavior. The most drastic change occurred in $\left[\mathrm{Fe}(\mathrm{btr})_{2}\right.$ $(\mathrm{NCS})_{2}$ ] (btr $=4,4^{\prime}$-bis-1,2,4-triazole), the hydrated form of which undergoes an abrupt transition with a hysteresis loop of $21 \mathrm{~K}$ centered at $134 \mathrm{~K}$, but the dehydrated form is a paramagnetic species at all temperatures. ${ }^{[21]}$ The triazole-based ligand 3-(2-pyridyl)[1,2,3]triazolo[1,5-a]pyridine) (tzpy) was first used for iron(II) SCO compounds by Niel et al. ${ }^{[22]}$ The solvated complexes $\left[\mathrm{Fe}^{\mathrm{II}}(\mathrm{tzpy})_{2}(\mathrm{NCS})_{2}\right] \cdot \mathrm{Sol} \quad\left(\mathrm{Sol}=2 \mathrm{CHCl}_{3}\right.$ (2) and $\mathrm{H}_{2} \mathrm{O}(3)$ ) were isolated and found to exhibit an incomplete ST with $T_{1 / 2}=108 \mathrm{~K}$ and a complete ST with $T_{1 / 2}=$ $118 \mathrm{~K}$ for $\mathbf{2}$ and $\mathbf{3}$, respectively. For $\mathbf{3}$, the LIESST phenomenon was detected below $70 \mathrm{~K}$ by magnetic measurement using Xe lamp with a $350-800 \mathrm{~nm}$ filter as the irradiation source; a rather slow relaxation process was observed with a rate of $3 \times 10^{-6} \mathrm{~s}^{-1}$ at $20 \mathrm{~K}$. This rate would make the compound a good candidate for structural analysis at its LIESST state. Herein we report two new polymorphs of the nonsolvated form $\mathbf{1 A}$ and $\mathbf{1 B}$ of trans-[Fe $\left.{ }^{\mathrm{II}}(\mathrm{tzpy})_{2}(\mathrm{NCS})_{2}\right]$; their syntheses, crystal structures, magnetic properties, as well as FTIR and X-ray absorption spectroscopy are presented. In particular, structural characterization at the metastable excited state (LIESST) of $\mathbf{1 A}$ is reported. The geometric change is believed to occur concurrently with the change in spin state of the iron(II) center. Because of its relatively fast relaxation from the metastable excited state, a "pump and probe" process was designed to measure the change in molecular structure by using single-crystal X-ray diffraction. The change in the electronic configuration was also monitored closely by Fe K- and L-edge absorption, FTIR spectroscopy, and magnetic susceptibility measurements.

\section{Results and Discussion}

Magnetic properties: Plots of the temperature dependence of the value of $\chi_{\mathrm{m}} T$ for polymorph $\mathbf{A}(\mathbf{1 A})$ and $\mathbf{B}(\mathbf{1 B})$ in the temperature range $2-300 \mathrm{~K}$ are displayed in Figure 1.

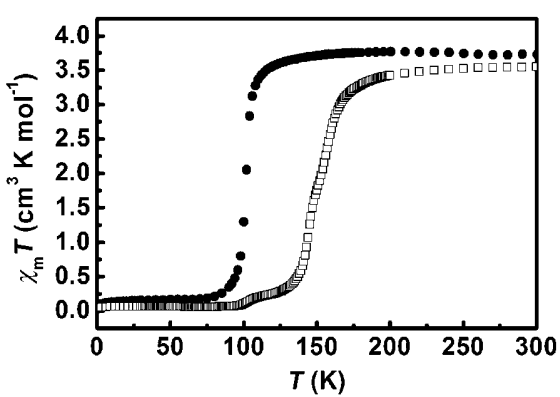

Figure 1. Temperature dependence of $\chi_{\mathrm{m}} T$ for $\mathbf{1 A}(\square)$ and $\mathbf{1 B}(\bullet)$.

The $\chi_{\mathrm{m}} T$ values of 3.6 and $3.7 \mathrm{~cm}^{3} \mathrm{~K} \mathrm{~mol}^{-1}$ at $300 \mathrm{~K}$ for $\mathbf{1 A}$ and $\mathbf{1 B}$, respectively, are within the range of expected values for a high-spin (HS) paramagnetic iron(II) center with some orbital contributions; they are roughly the same as those of the reported solvated complexes. ${ }^{[22]}$ For $\mathbf{1 B}$, the value of $\chi_{\mathrm{m}} T$ remains almost constant as the temperature is lowered until $102 \mathrm{~K}$, where it drops abruptly to nearly zero. However, 1A exhibits somewhat gradual transition between 180 to $120 \mathrm{~K}$. The small residual signal at $120-140 \mathrm{~K}$ is due to the presence of small amount of $\mathbf{1 B}$. The near-zero $\chi_{\mathrm{m}} T$ values for both polymorphs at temperatures below the ST suggest that both undergo a rather complete ST. The abruptness, defined as the temperature difference for which $80 \%$ and $20 \%$ of the molecules are HS, ${ }^{[23]}$ for $\mathbf{1 A}$ and $\mathbf{1 B}$ is 21 and $8 \mathrm{~K}$, respectively. To ensure the purity of the polymorphs, the powder X-ray diffraction pattern was checked for every sample used in magnetic susceptibility measurement. However, the existence of small amount of $\mathbf{1 B}$ in $\mathbf{1 A}$ is hard to prevent completely. Apparently, these complexes display strongly solvent-dependent magnetic behavior; ;22] $^{[2]}$ 
even the nonsolvated forms $\mathbf{1 A}$ and $\mathbf{1 B}$ are different from each other, structural analyses of both polymorphs were therefore undertaken.

Crystal and molecular structure of $1 \mathrm{~A}$ at $300 \mathrm{~K}$ (HS-1) and of $1 \mathrm{~B}$ at $150 \mathrm{~K}$ (HS-1): The molecular structure of $1 \mathrm{~A}$ is displayed in Figure 2 together with the atomic labeling scheme.

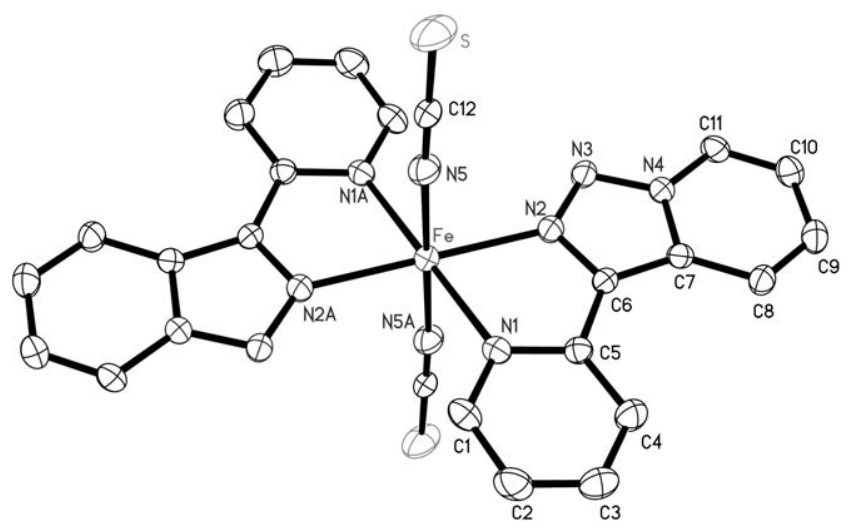

Figure 2. ORTEP drawing with atomic labeling of $\mathbf{1} \mathbf{A}$ at $30 \%$ probability level of thermal ellipsoids at $300 \mathrm{~K}$.

The complex crystallizes in monoclinic space group $P 2_{1} / c$ with cell constants $a=8.760(1), b=17.476$ (2), $c=8.367$ (1) $\AA$, $\beta=103.78(1)^{\circ}$ at $300 \mathrm{~K}$ (HS-1). The iron(II) atom is located at the inversion center in a distorted octahedron environment, which is coordinated to two tzpy ligands at the equatorial positions and two $\mathrm{NCS}^{-}$groups at the axial positions in a trans fashion. Complex $1 \mathbf{B}$ crystallizes in triclinic space group $P \overline{1}$ with cell constants $a=8.2884(3), \quad b=$ 8.7652(3), $c=9.3434(3) \AA, \alpha=68.071(2), \beta=103.78(1), \gamma=$ $75.648(2)^{\circ}$. The molecular structure is virtually the same as that of the polymorph $\mathbf{A}$ with some deviations in $\mathrm{Fe}-\mathrm{N}$ bond lengths; the bond lengths of $\mathrm{Fe}-\mathrm{N}(\mathbf{1 A} ; \mathbf{1 B})$ are 2.217(2) and 2.193(1) $\AA$ for metal to pyridine, 2.181(2) and 2.174(1) A for metal to triazole, and 2.097(3) and 2.107(2) $\AA$ for metal to thiocyanate, which are very similar to those of the $\mathrm{CHCl}_{3}$-solavated structure $(2.204(2), 2.211(2)$, and 2.113(3) $\AA$ ). ${ }^{[22]}$ The difference in $\mathrm{Fe}-\mathrm{N}_{\mathrm{py}}$ bond length between $\mathbf{A}$ and $\mathbf{B}$ appears to be significant; however, the two crystal structures were measured at different temperature $(300,150 \mathrm{~K})$, and the difference may be smaller when corrected for thermal libration. The molecules in the crystal form a sheet structure along the $a c$ and $a b$ plane for $\mathbf{1 A}$ and $\mathbf{1 B}$, respectively, through $\pi-\pi$ interactions between the adjacent parallel tzpy planes, as shown in Figure 3 a. Two types of overlapping modes through $\pi-\pi$ interactions are found with distances of 3.608(6) and 3.352(6) $\AA$ for $\mathbf{1 A}$, and 3.364(2) and 3.257(2) $\AA$ for 1B. Short contacts were found between the sheets through $\mathrm{S}$... $\mathrm{H}-\mathrm{C} 11$ interactions to be 3.482(3) $\AA$ for $\mathbf{1 A}$ and through $\mathrm{S} \cdot \cdots \mathrm{H}-\mathrm{C} 10$ to be 3.621(2) $\AA$ for $\mathbf{1 B}$. Up to this point, one can see there is no significant difference in molecular geometries or in packing of the sheet structures; however, the intralayer $\pi-\pi$ distances of
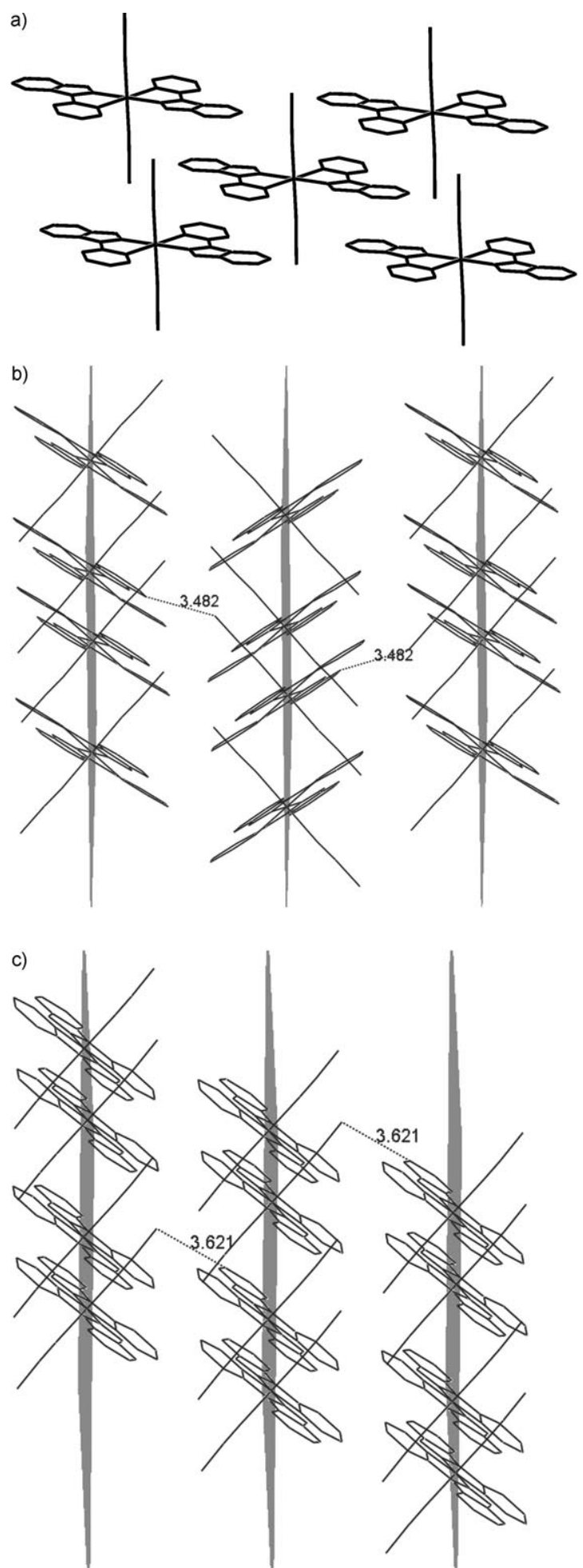

Figure 3. a) Packing diagram describing the sheet structure; close contacts between sheets of complex $\mathbf{1 A}$ (b) and $\mathbf{1 B}$ (c).

$\mathbf{1 B}$ are shorter than those of $\mathbf{1 A}$, and the short contact between the sheets of $\mathbf{1 B}$ is, in contrast, longer than that of 1A. The significant difference is that the relative orientations of the tzpy planes between the adjacent sheets is perpendicular in the case of $\mathbf{1 A}$ but parallel in the case of $\mathbf{1 B}$ 
(Figure 3b,c). Nevertheless, this change causes the large difference in magnetic behavior shown above. This result seems to indicate that even the difference in secondary structure could affect the magnetic properties.

Crystal and molecular structure of $1 \mathrm{~A}$ at $40 \mathrm{~K}$ (LS-1): The space group of $\mathbf{1 A}$ remains unchanged below the transition temperature (Table 1). The unit cell volume at $40 \mathrm{~K}$ is $6.6 \%$ smaller than that of the $300 \mathrm{~K}$ as a consequence of thermal reduction and smaller molecular volume. As expected, the coordination geometry of the iron site is strongly dependent on the spin state of the iron(II) center. The typical difference in bond length of the two spin states is around $0.2 \AA$ for $\mathrm{Fe}-\mathrm{N}$; the $\mathrm{Fe}-\mathrm{N}$ distances are 2.021(1), 1.973(1), and 1.935(1) $\AA$ in the low-spin state LS-1. The distortion parameters of the octahedron, $\Sigma^{[24]}$ and $\Theta,{ }^{[9]}$ defined respectively as the sum of the deviation from $90^{\circ}$ of 12 cis $\mathrm{N}-\mathrm{Fe}-\mathrm{N}$ angles and from $60^{\circ}$ of 24 twist angles between two triangular planes, are $74.8^{\circ}$ and $271.5^{\circ}$ at HS-1 state and $52.0^{\circ}$ and $171.4^{\circ}$ at LS-1. Thus, the $\mathrm{FeN}_{6}$ octahedron in the LS state is much closer to a regular octahedron environment, as found in other SCO compounds containing diimine bidentate ligands. ${ }^{[9,23]}$ The intralayer distances between tzpy ligands of neighboring molecules are shortened to 3.516(2) and

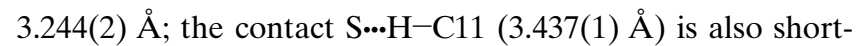
er than that of the HS state.

Electronic configuration: The changes in spin state or electronic configuration of iron(II) were investigated by Fe Kand L-edge absorption spectroscopy, which is very sensitive not only to the oxidation state but also to the electronic density distribution around the metal center. Previous studies with $\mathrm{K}$ - and L-edge absorption spectroscopy have established the spectroscopic fingerprints of HS and LS iron(II) spin-crossover complexes. ${ }^{[25,26]}$ The Fe K-edge X-ray nearedge absorption structure (XANES) spectra of $\mathbf{1 A}$ at $300 \mathrm{~K}$ (HS-1) and at $10 \mathrm{~K}$ (LS-1) are shown in Figure $4 \mathrm{a}$. Typical spectra of six-coordinate iron(II) complexes in the HS and LS states were well-characterized and indicate a significantly shortening in $\mathrm{Fe}-\mathrm{N}$ distances going from HS to LS. Furthermore, 1) the intensity of the main resonance is lower and the peak position is shifted to higher energy (from 7127.0 to $7129.8 \mathrm{eV})$; 2) the shoulder points to a multiple scattering processes, which is stronger in intensity and is shifted to a higher energy, and 3) the broad feature arising from scattering of the photoelectron by the nearest-neighbor nitrogen shell is also shifted to higher energy. The Fe $\mathrm{L}_{2,3}$-edge absorption spectra of $\mathbf{1 A}$ for HS-1 at $300 \mathrm{~K}$ and LS-1 at $24 \mathrm{~K}$

Table 1. Crystal data and structure refinement for trans-[Fe(tzpy $\left.)_{2}(\mathrm{NCS})_{2}\right]$

\begin{tabular}{|c|c|c|c|c|}
\hline Compound & Polymorph A & Polymorph A & Polymorph A & Polymorph B \\
\hline empirical formula & $\mathrm{C}_{24} \mathrm{H}_{16} \mathrm{~N}_{10} \mathrm{~S}_{2} \mathrm{Fe}$ & $\mathrm{C}_{24} \mathrm{H}_{16} \mathrm{~N}_{10} \mathrm{~S}_{2} \mathrm{Fe}$ & $\mathrm{C}_{24} \mathrm{H}_{16} \mathrm{~N}_{10} \mathrm{~S}_{2} \mathrm{Fe}$ & $\mathrm{C}_{24} \mathrm{H}_{16} \mathrm{~N}_{10} \mathrm{~S}_{2} \mathrm{Fe}$ \\
\hline formula weight & 564.44 & 564.44 & 564.44 & 564.44 \\
\hline temperature $[\mathrm{K}]$ & 300(2) HS-1 & 40(2) LS-1 & 40(2) HS-2 & 150(2) HS-1 \\
\hline wavelength [̊̊] & 0.71073 & 0.5886 & 0.5886 & $0.71073 \AA$ \\
\hline crystal system, space group & monoclinic, $P 2_{1} / c$ & monoclinic, $P 2_{1} / c$ & monoclinic, $P 2_{1} / c$ & triclinic, $P \overline{1}$ \\
\hline$a[\AA]$ & $8.7600(5)$ & $8.5390(3)$ & $8.6530(5)$ & $8.2884(3)$ \\
\hline$b[\AA]$ & $17.4760(16)$ & $17.2110(6)$ & $17.4010(9)$ & $8.7652(3)$ \\
\hline$\alpha\left[^{\circ}\right]$ & 90 & 90 & 90 & $68.071(2)$ \\
\hline$\beta\left[^{\circ}\right]$ & $103.781(6)$ & $105.676(3)$ & $103.230(5)$ & $72.302(2)$ \\
\hline$\gamma\left[^{\circ}\right]$ & 90 & 90 & 90 & $75.648(2)$ \\
\hline volume $\left[\AA^{3}\right]$ & $1244.03(16)$ & $1161.42(8)$ & $1201.18(13)$ & $592.91(4)$ \\
\hline$Z$, calculated density $\left[\mathrm{Mg} \mathrm{m}^{-3}\right]$ & $2,1.507$ & $2,1.614$ & $2,1.561$ & $1,1.581$ \\
\hline absorption coefficient $\left[\mathrm{mm}^{-1}\right]$ & 0.810 & 0.455 & 0.440 & 0.849 \\
\hline$F(000)$ & 576 & 576 & 576 & 288 \\
\hline crystal size $\left[\mathrm{mm}^{3}\right]$ & $0.30 \times 0.25 \times 0.15$ & $0.13 \times 0.05 \times 0.03$ & $0.13 \times 0.05 \times 0.03$ & $0.30 \times 0.10 \times 0.05$ \\
\hline \multirow[t]{3}{*}{ limiting indices } & $-8 \leq h \leq 10$ & $0 \leq h \leq 14$ & $0 \leq h \leq 15$ & $-10 \leq h \leq 10$ \\
\hline & $-20 \leq k \leq 20$ & $0 \leq k \leq 34$ & $0 \leq k \leq 34$ & $-10 \leq k \leq 11$ \\
\hline & $-9 \leq \bar{l} \leq \overline{9}$ & $-\overline{16} \leq l \leq 15$ & $-\overline{16} \leq l \leq 15$ & $-12 \leq l \leq 12$ \\
\hline \multirow[t]{2}{*}{ reflections collected/unique } & $10404 / 2189$ & $42142 / 7686$ & $45540 / 7487$ & $10013 / 2692$ \\
\hline & {$[R($ int $)=0.038]$} & {$[R($ int $)=0.040]$} & {$[R($ int $)=0.040]$} & {$[R($ int $)=0.048]$} \\
\hline completeness of data [\%] & 99.9 & 78.6 & 74.0 & 98.5 \\
\hline absorption correction method & SADABS & NONE & NONE & SADABS \\
\hline refinement method & $\begin{array}{l}\text { full-matrix least-squares on } \\
F^{2}\end{array}$ & $\begin{array}{l}\text { full-matrix least-squares on } \\
F^{2}\end{array}$ & $\begin{array}{l}\text { full-matrix least-squares on } \\
F^{2}\end{array}$ & $\begin{array}{l}\text { full-matrix least-squares on } \\
F^{2}\end{array}$ \\
\hline data/restraints/parameters & $2189 / 0 / 169$ & $7686 / 0 / 169$ & $7487 / 0 / 169$ & $2692 / 0 / 169$ \\
\hline goodness-of-fit on $F^{2}$ & 1.143 & 1.432 & 1.290 & 0.876 \\
\hline \multirow[t]{2}{*}{ final $R$ indices $[I>2 \sigma(I)]$} & $R 1=0.0403$ & $R 1=0.0433$ & $R 1=0.0458$ & $R 1=0.0301$ \\
\hline & $\mathrm{w} R 2=0.1035$ & $\mathrm{w} R 2=0.1243$ & $\mathrm{w} R 2=0.1205$ & $\mathrm{w} R 2=0.0569$ \\
\hline \multirow[t]{2}{*}{$R$ indices (all data) } & $R 1=0.0656$ & $R 1=0.0523$ & $R 1=0.0635$ & $R 1=0.0491$ \\
\hline & $\mathrm{w} R 2=0.1135$ & $w R 2=0.1301$ & $\mathrm{w} R 2=0.1299$ & $\mathrm{w} R 2=0.0585$ \\
\hline $\begin{array}{l}\text { largest diff. peak and hole } \\
{\left[\mathrm{e} \AA^{-3}\right]}\end{array}$ & 0.428 and -0.336 & 0.904 and -1.679 & 1.020 and -1.443 & 0.327 and -0.250 \\
\hline
\end{tabular}



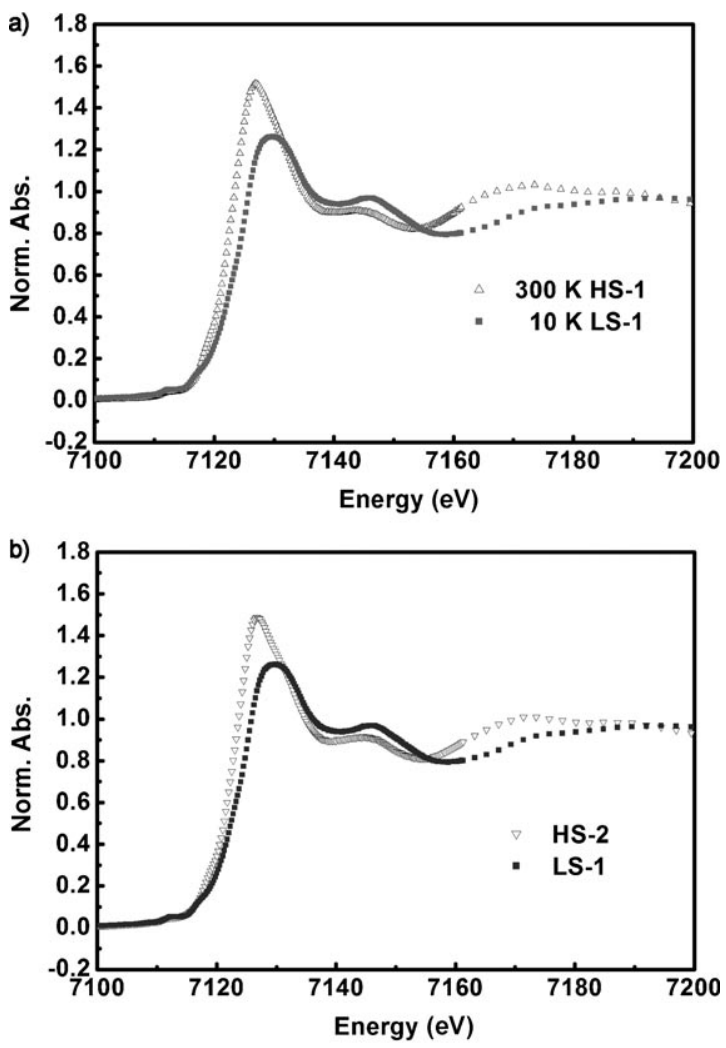

Figure 4. Fe K-edge absorption spectra of $\mathbf{1 A}$ : a) HS-1 at $300 \mathrm{~K}$ and LS-1 at $10 \mathrm{~K}$; b) before (LS-1) and after laser irradiation (HS-2) at $10 \mathrm{~K}$.

are shown in Figure 5. The shift in energy, change in structure of the principal spectral features, and the different branching ratio between the HS and LS states agree well with the experimental data and the result of multiplet calculation of $\left[\mathrm{Fe}^{\mathrm{II}}(\mathrm{phen})_{2}(\mathrm{NCS})_{2}\right] \quad($ phen $=1,10$-phenanthroline). ${ }^{[26]}$

LIESST phenomenon: The Fe K-edge absorption spectra of the compound $\mathbf{1 A}$ in both spin states are shown in Figure $4 \mathrm{a}$, and the LIESST phenomenon is depicted in Figure $4 \mathrm{~b}$, which shows spectra before and after the irradiation at $10 \mathrm{~K}$. The same phenomenon is demonstrated in the Ledge absorption spectra, which are shown for LS-1 and HS2 at $24 \mathrm{~K}$ in Figure 5 before and after irradiation; HS- 1 at $300 \mathrm{~K}$ and LS-2 at $70 \mathrm{~K}$ are also included for reference. As noticed previously, the $\mathrm{Fe}-\mathrm{N}$ distance of the HS-2 state is slightly shorter than that of the HS-1 state according to the EXAFS investigation; ${ }^{[26]}$ this difference was later confirmed by the diffraction work, ${ }^{[8 \mathrm{e}]}$ which revealed values of 2.177 and $2.199 \AA$ for the HS- 2 and HS-1 states, respectively. However, a study of $\left[\mathrm{Fe}(\text { phen })_{2}(\mathrm{NCSe})_{2}\right]^{[8 \mathrm{k}]}$ claimed the opposite effect, whereby slight lengthening of the $\mathrm{Fe}-\mathrm{N}$ distance in HS-2 was found, although no thermal effects on the bond length were taken into account.

The changes in spin state not only introduce the change of the $\mathrm{Fe}$ coordination geometry but also affect the bond strength of the $\mathrm{C} \equiv \mathrm{N}$ bond in the NCS ligand. ${ }^{[27]}$ The $\mathrm{CN}$

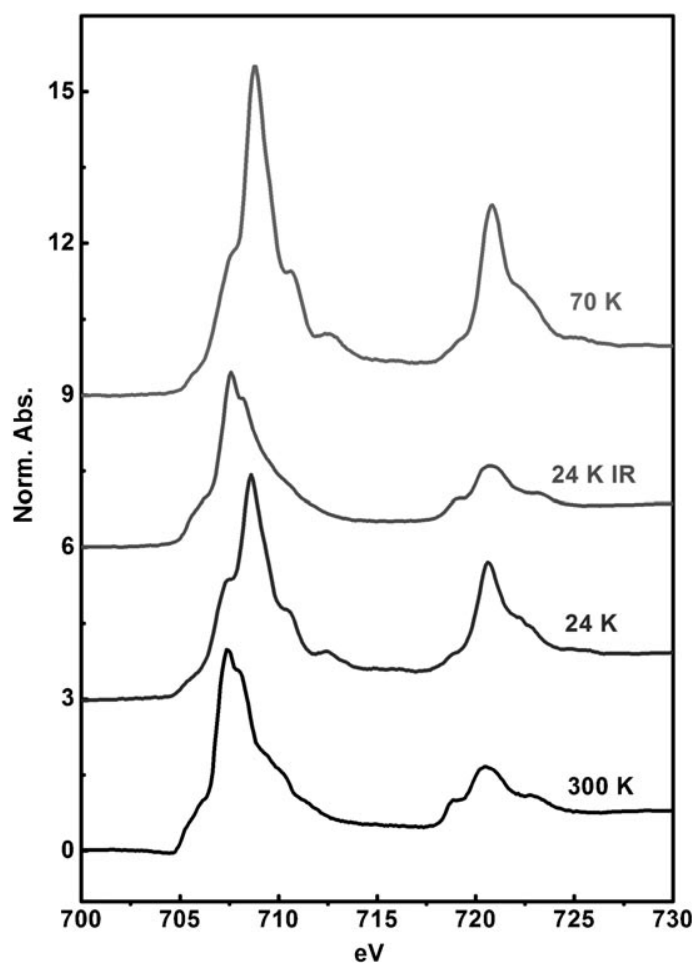

Figure 5. Fe L-edge spectra for $\mathbf{1 A}$ at $300 \mathrm{~K}$ (HS-1), before (LS-1) and after (HS-2) laser irradiation at $24 \mathrm{~K}$, and after laser relaxation at $70 \mathrm{~K}$ (LS-2).

stretching frequency shows a broad band around $2075 \mathrm{~cm}^{-1}$ in the HS state, but a relatively sharp absorption at $2116 \mathrm{~cm}^{-1}$ only for the LS state. The IR absorption spectra at various temperatures and the LIESST phenomenon at $15 \mathrm{~K}$ are depicted in Figure 6; IR spectroscopy gives a quick and efficient way of monitoring the ST of the title compound. The fraction of LS state can be derived from the peak height at $2116 \mathrm{~cm}^{-1}$; thus, the complete disappearance of the peak at $2116 \mathrm{~cm}^{-1}$ indicates $100 \%$ of the LS to HS transition after irradiation.

By monitoring the peak height at $2116 \mathrm{~cm}^{-1}$, the relaxations of LIESST state after irradiation at various tempera-

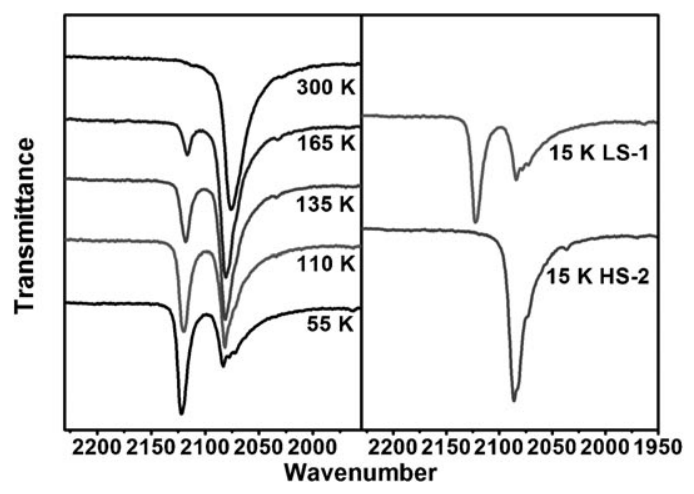

Figure 6. Temperature-dependent FTIR spectra of 1A (left), and FTIR spectra before and after laser irradiation at $15 \mathrm{~K}$ (right). 
tures were studied (Figure 7). It is apparent that the lower the temperature, the slower the relaxation proceeds. However, in this case, even at $30 \mathrm{~K}$, there is more than $10 \%$ decay

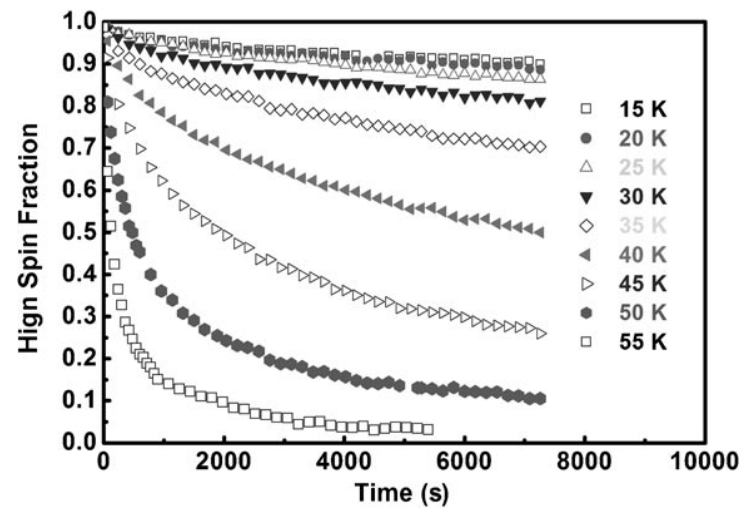

Figure 7. The temperature-dependent relaxation curves of $\mathbf{1 A}$ in the LIESST state.

after 1 hour; however, at least a few hours are needed to complete the single-crystal diffraction measurements. In order to know whether the excitation can take place at any stage of the relaxation process, a periodic pumping with $532 \mathrm{~nm}$ light was performed at $30 \mathrm{~K}$. A fully excited state can be reached at any stage of the relaxation process, as shown in Figure 8. To make sure of complete formation of

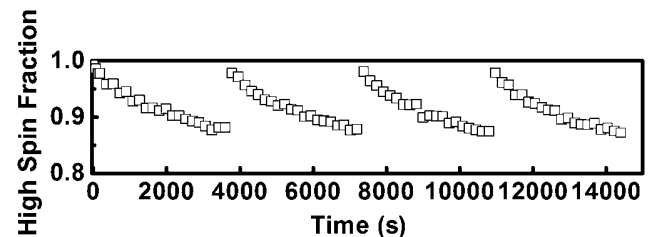

Figure 8. Periodic excitation at $30 \mathrm{~K}$ of $\mathbf{1 A}$ with light for $10 \mathrm{~s}$ every hour.

the HS-2 state as well as to avoid possible damage to the sample crystal as a result of long exposure to the laser light during the measurement of diffraction data, a pump and probe experiment was thus designed. Crystal structures at LIESST state (HS-2) are currently not so widely available, ${ }^{[8]}$ which may be due to the fast relaxation of the metastable state; more structures could be obtained with such a design.

The LIESST phenomenon for both $\mathbf{1 A}$ and $\mathbf{1 B}$ was also monitored with photomagnetic measurements (Figure 9). The excitation took place at $5 \mathrm{~K}$ with $532 \mathrm{~nm}$ laser source for $30 \mathrm{~min}$ before warming, the ST to HS-2 was clearly $100 \%$ complete; the relaxation took place only above $50 \mathrm{~K}$ with $T$ (LIESST) values of 54 and $67 \mathrm{~K}$, respectively, for $\mathbf{1 A}$ and $1 \mathbf{B}$; these values follow a relation between $T$ (LIESST) and thermal ST $\left(T_{1 / 2}\right)$ of $T(\operatorname{LIESST})=T_{0}-0.3 T_{1 / 2}$ with $T_{0}=$ 100 for some $\left[\mathrm{FeL}_{2}(\mathrm{NCX})_{2}\right]$ compounds. ${ }^{[10]}$

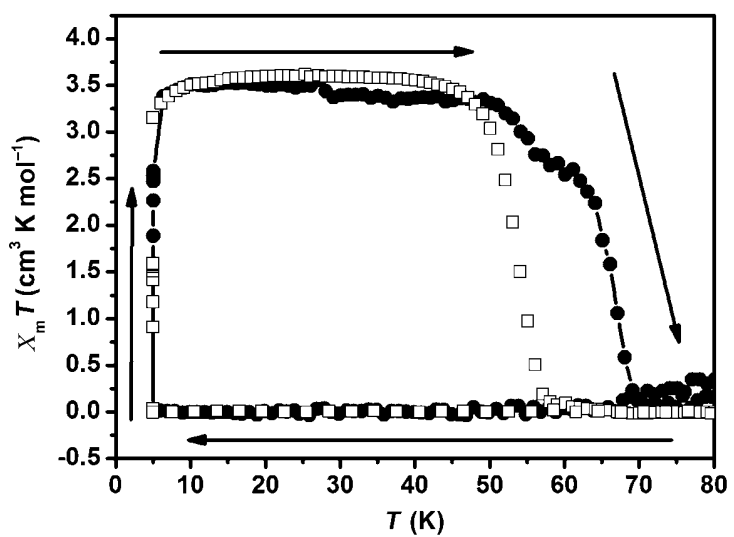

Figure 9. Relaxation from photomagnetic measurements of $\mathbf{1 A}$ ( $\square$ ) and $1 \mathbf{B}(\bullet)$ The irradiation of sample takes place at $5 \mathrm{~K}$ for $30 \mathrm{~min}$, the data were then recorded in warming mode at $0.3 \mathrm{~K} \mathrm{~min}^{-1}$.

Single-crystal structure of LIESST complex $1 \mathrm{~A}$ at $40 \mathrm{~K}$ : The single-crystal structure of LIESST state HS-2 at $40 \mathrm{~K}$ was investigated by pumping the crystal with $532 \mathrm{~nm}$ laser light and probing by $\mathrm{X}$-ray diffraction at a wavelength of $0.5886 \AA$. Diffraction data were measured by image plates in a vacuum camera at beamline BL02B1 at the SPring- 8 facility. The pumping condition was chosen to be the minimum in power and time (11 $\mathrm{mW}$ and $30 \mathrm{~s})$ to excite fully from the LS to the HS state. The LIESST phenomenon is demonstrated by the single-frame diffraction patterns shown in Figure 10. The diffraction pattern is different before (a) and after (b) the irradiation. In particular, for example, re-

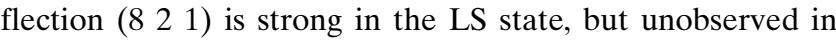
the HS state; other examples are shown in the area within the thick box. In addition, the peak positions after irradiation (HS-2) are, in general, shifted to lower angle, indicating a larger unit cell, as expected for the HS versus the LS state. A full data set was collected in such a way that each frame was measured after $30 \mathrm{~s}$ of irradiation. A total of 60 frames were measured up to $2 \theta$ of $50^{\circ}$. The space group remained unchanged throughout the excitation; the molecular and crystal structures are essentially the same as HS-1; the tzpy $\pi-\pi$ distances within the sheet are only slightly lengthened from the LS-1 state of 3.516(2) and 3.244(2) $\AA$ to the HS-2 state of 3.548(2) and 3.261(2) $\AA$, respectively. The close contact distance between the sheets $(\mathrm{S} \cdots \mathrm{H}-\mathrm{C} 11)$ was found to be 3.482(3) $\AA$ in the HS- 1 state, 3.437(1) $\AA$ in the LS-1 state, and 3.391(1) $\AA$ in the HS-2 state. Both of the molecular geometries and the crystal packing at this LIESST state are very similar to those of HS- 1 . The $\pi-\pi$ interactions are believed to be important for the spin-transition temperature,${ }^{[12,17]}$ as well as the LIESST phenomenon. ${ }^{[28]}$ In the case of polymorph $\mathbf{1 A}$ and $\mathbf{1 B}$, the $\pi-\pi$ interactions are roughly the same except that the intralayer distances differ slightly, yet the thermal spin-transition temperature and the photorelaxation temperature $T$ (LIESST) are significantly different. Before any conclusions can be drawn about whether this effect could be correlated with the difference in distan- 


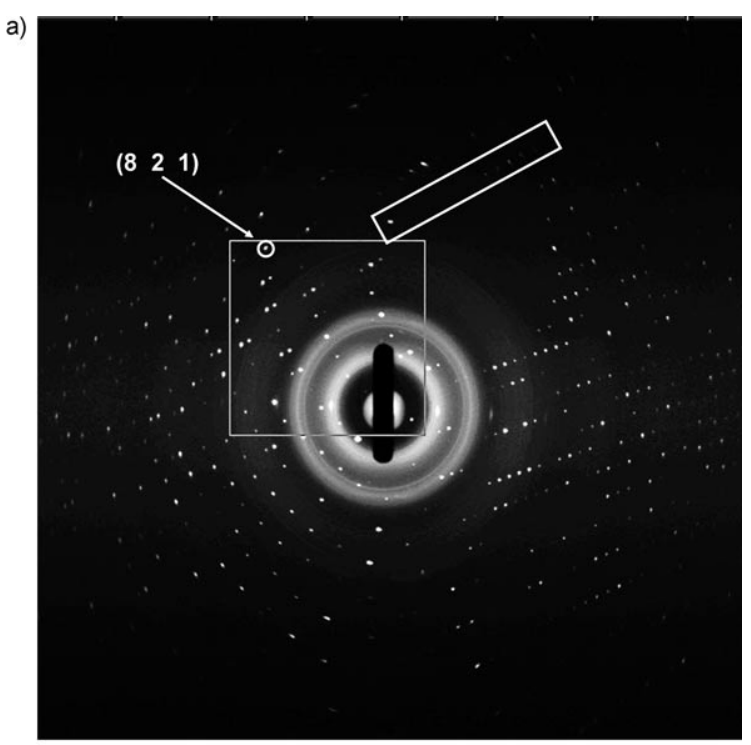

b)

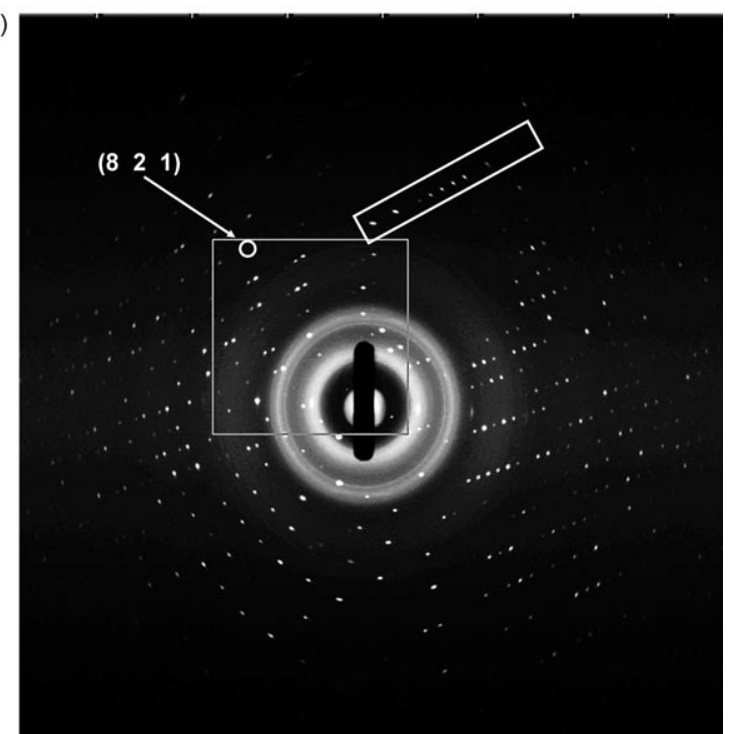

Figure 10. Diffraction patterns of $\mathbf{1} \mathbf{A}$ before (a) and after (b) the irradiation at $40 \mathrm{~K}$. Differences between the pattern are highlighted by the circle and thick box.

ces and in secondary structure, more systems of the sort should be investigated.

Going from HS- 1 at $300 \mathrm{~K}$ to LS- 1 at $40 \mathrm{~K}$, the volume of unit cell is reduced by $6.6 \%$, and $3.4 \%$ volume is regained after irradiation to HS-2 at $40 \mathrm{~K}$. Such an increase in volume after irradiation is due to the increase in Fe coordination domain going from the LS to the HS states. The $\mathrm{Fe}-$ $\mathrm{N}$ bond lengths are shortened by approximately $0.2 \AA$ from HS-1 to LS-1 and lengthened by about the same amount after irradiation to become HS-2. The exact bond lengths are listed in Table 2. Such changes in $\mathrm{Fe}-\mathrm{N}$ distances are very typical for the ST of iron(II) complexes. The volumes of $\mathrm{FeN}_{6}$ octahedron are calculated as $13.1,10.1$, and $12.8 \AA^{3}$ for HS-1, LS-1, and HS-2, respectively. The octahedron distortion parameters, $\Sigma^{[24]}$ and $\Theta,{ }^{[9]}$ a measure of the extent of distortion from a regular octahedron, are also listed in
Table 2. $\mathrm{FeN}_{6}$ octahedron geometry versus spin state for trans-[Fe(tzpy) $)_{2}$ $\left.(\mathrm{NCS})_{2}\right]$

\begin{tabular}{|c|c|c|c|c|c|c|}
\hline$T[\mathrm{~K}]$ & $\begin{array}{l}\text { Spin } \\
\text { state }\end{array}$ & $\begin{array}{l}\mathrm{Fe}-\mathrm{N} 1 \\
{[\AA]}\end{array}$ & $\begin{array}{l}\mathrm{Fe}-\mathrm{N} 2 \\
{[\AA]}\end{array}$ & $\begin{array}{l}\mathrm{Fe}-\mathrm{N} 5 \\
{[\AA]}\end{array}$ & $\begin{array}{l}\sum^{[\mathrm{a}]} \\
\left.{ }^{\circ}\right] \\
\end{array}$ & $\begin{array}{l}\Theta^{[\mathrm{b}]} \\
{\left[^{\circ}\right]} \\
\end{array}$ \\
\hline \multicolumn{7}{|c|}{ Polymorph A } \\
\hline 300 & HS-1 & $2.217(2)$ & $2.181(2)$ & $2.097(3)$ & 74.8 & 271.5 \\
\hline 40 & LS-1 & $2.021(1)$ & $1.973(1)$ & $1.935(1)$ & 52.0 & 171.4 \\
\hline $\begin{array}{l}40 \\
\text { (LIESST) }\end{array}$ & HS-2 & $2.211(1)$ & $2.166(1)$ & $2.087(1)$ & 77.0 & 267.0 \\
\hline \multicolumn{7}{|c|}{ Polymorph B } \\
\hline 150 & HS & $2.193(1)$ & $2.174(1)$ & $2.107(2)$ & 72.7 & 272.0 \\
\hline
\end{tabular}

[a] The distortion parameter $\Sigma$, which is defined as the sum of the absolute values of the deviation from $90^{\circ}$ of the 12 cis angles in the coordination sphere. [b] The distortion parameter $\Theta$, which is defined as the sum of the deviations from $60^{\circ}$ of the 24 possible $\theta$ angles on the dihedral angles between two triangular planes.

Table 2; the coordination geometry of the low-spin state is much closer to a regular octahedron than that of the highspin state, which is often the case in many other spin-crossover systems. ${ }^{[9,23]}$ This observation is consistent with other reported spin-crossover complexes, for example, $\left[\mathrm{Fe}(\mathrm{phen})_{2^{-}}\right.$ $\left.(\mathrm{NCS})_{2}\right]^{[8 \mathrm{e}]}$ and $\left[\mathrm{Fe}(\text { phen })_{2}(\mathrm{NCSe})_{2}\right] \cdot{ }^{[8 \mathrm{k}]}$ Selected anisotropic thermal displacements are given in Table 3. Apparently, the $u_{i j}$ values at HS-2 are only slightly greater than those of LS1 but significantly smaller than those of HS-1, indicating that the irradiation should purely induce the electronic excitation of Fe; no significant heating effect on the crystal occurred. Molecular structures before (LS-1) and after (HS-2) the irradiation at $40 \mathrm{~K}$ are superimposed in Figure 11; not only the lengthening of the $\mathrm{Fe}-\mathrm{N}$ but also the slight twist of the tzpy ligand is observed.

Table 3. Thermal displacement parameters $\left[\AA^{2} \times 10^{3}\right]$ at $300 \mathrm{~K}(\mathrm{HS}-1)$, $40 \mathrm{~K}$ (LS-1), and $40 \mathrm{~K}$ (HS-2).

\begin{tabular}{llllll}
\hline$T[\mathrm{~K}]$ & & $U_{11}$ & $U_{22}$ & $U_{33}$ & $U_{\text {eq }}$ \\
\hline $300 \mathrm{HS}-1$ & $\mathrm{Fe}$ & $35(1)$ & $34(1)$ & $33(1)$ & $34(1)$ \\
$40 \mathrm{LS}-1$ & & $10(1)$ & $4(1)$ & $11(1)$ & $8(1)$ \\
$40 \mathrm{HS}-2$ & & $12(1)$ & $8(1)$ & $10(1)$ & $10(1)$ \\
$300 \mathrm{HS}-1$ & $\mathrm{~N} 1$ & $35(1)$ & $33(1)$ & $40(1)$ & $36(1)$ \\
$40 \mathrm{LS}-1$ & & $11(1)$ & $6(1)$ & $14(1)$ & $10(1)$ \\
$40 \mathrm{HS}-2$ & & $12(1)$ & $9(1)$ & $15(1)$ & $12(1)$ \\
$300 \mathrm{HS}-1$ & $\mathrm{~N} 2$ & $42(1)$ & $35(1)$ & $36(1)$ & $38(1)$ \\
$40 \mathrm{LS}-1$ & & $12(1)$ & $5(1)$ & $13(1)$ & $10(1)$ \\
$40 \mathrm{HS}-2$ & & $14(1)$ & $9(1)$ & $13(1)$ & $12(1)$ \\
$300 \mathrm{HS}-1$ & $\mathrm{~N} 5$ & $45(1)$ & $37(1)$ & $38(1)$ & $36(1)$ \\
$40 \mathrm{LS}-1$ & & $13(1)$ & $7(1)$ & $14(1)$ & $11(1)$ \\
$40 \mathrm{HS}-2$ & & $16(1)$ & $14(1)$ & $15(1)$ & $15(1)$ \\
\hline
\end{tabular}

\section{Conclusion}

In summary, the exact electronic configurations of the $\mathrm{Fe}$ center in the HS-1, LS-1, and HS-2 (LIESST) states are clearly confirmed by $\mathrm{Fe} \mathrm{K}$ - and L-edge absorption spectroscopy and photomagnetic measurements. The molecular structure of the LIESST state (HS-2) was successfully obtained by diffraction data with a pump and probe process. By applying such a procedure, the structural determination 


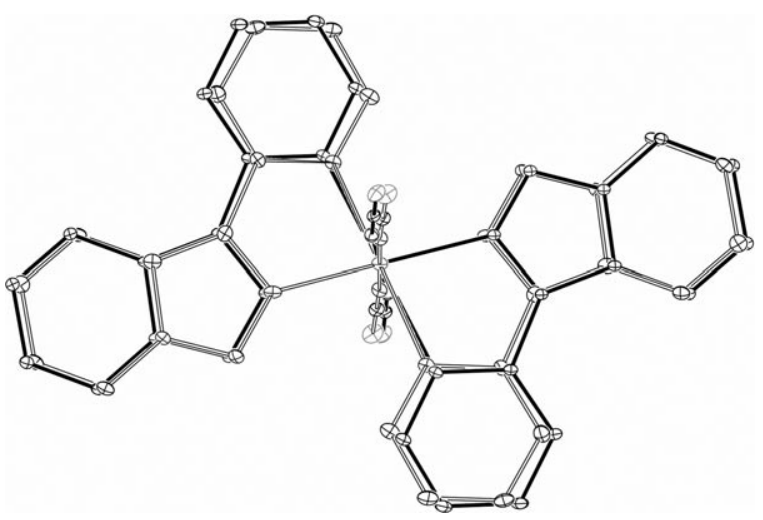

Figure 11. Superimposed molecular structures of $\mathbf{1 A}$ at $40 \mathrm{~K}$ in the LS-1 and HS-2 (LIESST) states, shown by hollow and solid bonds, respectively.

of any metastable excited state with moderate relaxation rate can be achieved. Molecular structure after the irradiation clearly shows the lengthening of the $\mathrm{Fe}-\mathrm{N}$ bond length and the slight twist of the coordination geometry in the solid state. The changes in spin state of Fe metal and in structural geometry of the complex take place concurrently.

\section{Experimental Section}

Synthesis: $\mathrm{FeSO}_{4} \cdot 7 \mathrm{H}_{2} \mathrm{O}$ and $\mathrm{KNCS}$ were purchased and used without further purification. The ligand tzpy was prepared by following a literature procedure $^{[29]}$ and confirmed by the unit-cell parameters and melting point. The compound was synthesized by slow diffusion between two layers of solution in a test tube under an argon atmosphere. The bottom layer contained $\mathrm{Fe}^{2+}(0.01 \mathrm{mmol}) / \mathrm{NCS}^{-}(0.02 \mathrm{mmol})$ in $10 \mathrm{~mL}$ of $1: 1$ $\mathrm{H}_{2} \mathrm{O} / \mathrm{MeOH}$, which was prepared by filtering off $\mathrm{K}_{2} \mathrm{SO}_{4}$ after mixing $\mathrm{FeSO}_{4} \cdot 7 \mathrm{H}_{2} \mathrm{O}$ and $\mathrm{KNCS}$ in $\mathrm{MeOH}$ and stirred for $15 \mathrm{~min}$. The top layer contained stoichiometric amounts of tzpy $(0.02 \mathrm{mmol})$ in $10 \mathrm{~mL}$ of $\mathrm{MeOH}$. After a week, brown crystals were obtained by filtering, in which polymorph $\mathbf{A}$ and $\mathbf{B}$ seem to grow simultaneously with yield roughly 70 and $30 \%$, respectively. Single crystals of polymorph $\mathbf{A}$ and $\mathbf{B}$ suitable for $\mathrm{X}$-ray diffraction were then selected manually under the microscope. Polymorph $\mathbf{A}$ and $\mathbf{B}$ display the same color but may be distinguished by crystal morphology, whereby crystals of $\mathbf{A}$ are mostly large and wellshaped but those of $\mathbf{B}$ are normally tiny. A small amount of polymorph $\mathbf{B}$ cannot be completely avoided in small crystal aggregates of A. Polymorph $\mathbf{B}$ can be obtained in powder form by mixing the reactants in $\mathrm{MeOH}$, but a single crystal is hard to obtain in this way.

Physical measurements: The magnetic susceptibility measurements at various temperatures were made on small crystal aggregate using a Quantum Design 1SQUID magnetometer (MPMS-XL7) operating at $0.2 \mathrm{~T}$. The photomagnetism experiment was performed by using an optical fiber (with $532 \mathrm{~nm}$ wavelength) installed in the sample rod holder. A small amount of sample in crystal form was used for the measurement to ensure the light penetration. The sample was cooled slowly to $5 \mathrm{~K}$ first, and the data was then measured in warming mode at $0.3 \mathrm{Kmin}^{-1}$ after $30 \mathrm{~min}$ of laser irradiation. The variable-temperature IR spectra were recorded using a Bomem DA8 FTIR spectrometer; samples were in the form of pressed $\mathrm{KBr}$ disk mounted on the cold head of a closed-cycle cryostat (APD). Fe K-edge absorption spectra were measured in florescence mode at BL-17C and Fe L-edge absorption spectra were collected in total electron yield mode at BL-20 A in National Synchrotron Radiation Research Center (NSRRC operation energy of $1.5 \mathrm{GeV}$ and stored current of 200-100 mA) in Taiwan, both equipped with an APD close- cycle cryostat for low-temperature measurements. The light source for LIESST experiments is a $20 \mathrm{~mW}$ diode laser with wavelength of $532 \mathrm{~nm}$.

Single-crystal X-ray structural analyses: Single-crystal diffraction data for polymorph $\mathbf{A}$ at $300 \mathrm{~K}$ (HS-1) were collected on an in-house BrukerKappa CCD machine, whereas the data of polymorph $\mathbf{B}$ at $150 \mathrm{~K}$ was measured on a Bruker X8 ApexCCD diffractometer using graphite-monochromated MoK $\alpha$ radiation source $(\lambda=0.71073 \AA)$. The software packages DNEZO $^{[30]}$ and SAINTPLUS ${ }^{[31]}$ were used to integrate the diffraction intensity, and the absorption correction was applied using SADABS. ${ }^{[32]}$

Single-crystal X-ray diffraction experiments at $40 \mathrm{~K}$ for both LS-1 and HS-2 of polymorph A were performed by using the low-temperature vacuum camera at beamline BL02B1 $(\lambda=0.5886 \AA)$ of the SPring- 8 facility. The data were collected by using an image-plate detector in Weisenburg geometry. A total of 60 frames were taken both for LS-1 and HS- 2 with rotation of $3^{\circ}$ for each frame in $3 \mathrm{~min}$. The reflections were indexed and the intensities were integrated using DENZO and subsequently scaled using Scalepack. ${ }^{[30]}$ The laser light source was introduced inside the camera with an optical fiber and positioned $10 \mathrm{~mm}$ away from the sample crystal. An exposure of $30 \mathrm{sec}$ of laser light was allowed before each frame of the diffraction data for HS-2 was taken. The completeness of the reflection data is less than $80 \%$ for both LS- 1 and HS- 2 of polymorph $\mathbf{A}$ because of the Weisenburg geometry of the vacuum camera. Remounting the crystal on a different orientation is necessary to reach the higher completeness; however, it is difficult to do so under the current circumstances. Nevertheless, the correctness of the structure is guaranteed, but the thermal parameters may be affected somewhat. Details of the unit cell and the refinement results are reported in Table 1. All the structures were solved by direct methods and refined on $F^{2}$ with fullmatrix least-squares analysis using SHELXS ${ }^{[33]}$ and SHELXL, ${ }^{[34]}$ respectively. For all data sets, non-hydrogen atoms were refined with anisotropic displacement parameters. The hydrogen atom positions were fixed geometrically at calculated distances and allowed to ride on the parent carbon atoms with $U_{\text {iso }}(\mathrm{H})=1.2 U_{\text {eq }}(\mathrm{C})$.

CCDC-298042, CCDC-298043, and CCDC-298044 for polymorph A and CCDC-707184 for B contain the supplementary crystallographic data for this paper. These data can be obtained free of charge from The Cambridge Crystallographic Data Centre via www.ccdc.cam.ac.uk/data request/cif.

\section{Acknowledgements}

This work was supported by the National Science Council (NSC) and the National Synchrocrotron Radiation Research Center (NSRRC). The single-crystal X-ray diffraction experiments at $40 \mathrm{~K}$ were performed at beamline BL02B1 in SPring-8 with approval of the Japan Synchrotron Radiation Research Institute (JASRI).

[1] a) P. Gütlich, H. A. Goodwin, Top. Curr. Chem. 2004, 233, 1-47; b) G. J. Halder, C. J. Kepert, B. Moubaraki, K. S. Murray, J. D. Cashion, Science, 2002, 298, 1762-1765; c) V. Niel, A. L. Thompson, M. C. Muñoz, A. Galet, A. E. Goeta, J. A. Real, Angew. Chem 2003, 115, 3890-3893; Angew. Chem. Int. Ed. 2003, 42, 3760-3763; d) H. A. Goodwin, Coord. Chem. Rev. 1976, 18(3), 293-325; e) P. Gütlich, A. Hauser, H. Spiering, Angew. Chem. 1994, 106, 2109; Angew. Chem. Int. Ed. Engl. 1994, 33, 2024 -2054; f) P. Gütlich, Y. Garcia, T. Woike, Coord. Chem. Rev. 2001, 219, 839-879; g) P. Gütlich, Y. Garcia, H. A. Goodwin, Chem. Soc. Rev. 2000, 29, 419-427; h) J. A. Real, A. B. Gaspar, M. C. Muñoz, Dalton Trans. 2005, $2062-$ 2079.

[2] a) J.-F. Létard, P. Guionneau, L. Goux-Capes, Top. Curr. Chem 2004, 235, 221-249; b) J. Zarembowitch, O. Kahn, New J. Chem. 1991, 15, 181-190; c) O. Kahn, J. Kröber, C. Jay, Adv. Mater. 1992 4, 718-728; d) O. Kahn, C. J. Martinez, Science, 1998, 279, 44-48; e) O. Kahn, Chem. Br. 1999, 35(2), 24-27; f) F. Renz, P. A. de Souza, 
G. Klingelhöfer, H. A. Goodwin, Hyperfine Interactions, 2002, 139/ 140, 699-704; g) A. Bousseksou, G. Molnar, C. R. Chim. C. R. Chimie 2003, 6, 1175-1183; h) F. Varret, A. Bleuzen, K. Boukheddaden, A. Bousseksou, E. Codjovi, C. Enachescu, A. Goujon, J. Linares, N. Menendez, M. Verdaguer, Pure Appl. Chem. 2002, 74(11), 2159-2168; i) A. Galet, A. B. Gaspar, M. C. Muñoz, G. V. Bukin, G. Levchenko, J. A. Real, Adv. Mater. 2005, 17, 2949-2953; j) M. Cavallini, I. Bergenti, S. Milita, G. Ruani, I. Salitros, Z.-R. Qu, R. Chandrasekar, M. Ruben, Angew. Chem. 2008, 120, 8724-8728; Angew. Chem. Int. Ed. 2008, 47, 8596-8600.

[3] a) S. Decurtins, P. Gütlich, C. P. Köhler, H. Spiering, A. Hauser, Chem. Phys. Lett. 1984, 105, 1-4; b) S. Decurtins, P. Gütlich, K. M. Hasselbach, A. Hauser, H. Spiering, Inorg. Chem. 1985, 24, 21742178 ; c) P. Gütlich, A. Hauser, Coord. Chem. Rev. 1990, 97, 1-22.

[4] A. B. Gaspar, V. Ksenofontov, M. Seredyuk, P. Gütlich, Coord. Chem. Rev. 2005, 249, 2661-2676.

[5] a) M. Seredyuk, A. B. Gaspar, V. Ksenofontov, S. Reiman, Y. Galyametdinov, W. Haase, E. Rentschler, P. Gütlich, Hyperfine Interact. 2005, 166, 385-390; b) M. Seredyuk, A. B. Gaspar, V. Ksenofontov, Y. Galyametdinov, J. Kusz, and P. Gütlich, J. Am. Chem. Soc. 2008, 130, 1431-1439; c) S. Hayami, N. Motokawa, A. Shuto, N. Masuhara, T. Someya, T. Ogawa, K. Inoue, Y. Maeda, Inorg. Chem. 2007, 46, 1789-1794; d) S. Hayami, N. Motokawa, A. Shuto, R. Moriyama, N. Masuhara, K. Inoue, Y. Maeda, Polyhedron 2007, 26, 23752380 .

[6] a) K. Takahashi, H.-B. Cui, Y. Okano, H. Kobayashi, H. Mori, H. Tajima, Y. Einaga, O. Sato, J. Am. Chem. Soc. 2008, 130, 66886689 ; b) C. Faulmann, K. Jacob, S. Dorbes, S. Lampert, I. Malfant, M.-L. Doublet, L. Valade, J. A. Real, Inorg. Chem. 2007, 46, 85488559; c) M. Nakano, N. Fujita, G. Matsubayashi, W. Mori, Mol. Cryst. Liq. Cryst. 2002, 379, 365-370; d) K. Takahashi, T. Kawakami, Z.-Z. Gu, Y. Einaga, A. Fujishima, O. Sato, Chem. Commun. 2003, 2374-2375; e) S. Dorbes, L. Valade, J. A. Real, C. Faulmann, Chem. Commun. 2005, 69-71; f) K. Takahashi, H.-B. Cui, H. Kobayashi, Y. Einaga, O. Sato, Chem. Lett. 2005, 34, 1240-1241; g) C. Faulmann, S. Dorbes, B. G. Bonneval, G. Molnaìr, A. Bousseksou, C. Gomez-Garcia, E. Coronado, L. Valade, Eur. J. Inorg. Chem. 2005, 3261-3270; h) K. Takahashi, H.-B. Cui, Y. Okano, H. Kobayashi, Y. Einaga, O. Sato, Inorg. Chem. 2006, 45, 5739-5741; i) C. Faulmann, S. Dorbes, S. Lampert, K. Jacob, B. G. Bonneval, G. Molnaìr, A. Bousseksou, J. A. Real, L. Valade, Inorg. Chim. Acta 2007, 360, 3870-3878; j) L. C. J. Pereira, A. M. Gulamhussen, J. C. Dias, I. C. Santos, M. Almeida, Inorg. Chim. Acta 2007, 360, 3887-3895.

[7] J.-B. Gaudry, L. Capes, P. Langot, S. Marcen, M. Kollmannsberger, O. Lavastre, E. Freysz, J.-F. Létard, O. Kahn, Chem. Phys. Lett. 2000, 324, 321-329.

[8] a) N. Huby, L. Guérin, E. Collet, L. Toupet, J. C. Ameline, H. Cailleau, T. Roisnel, T. Tayagaki, K. Tanaka, Phys. Rev. B, 2004, 69, 020101(R); b) J. Kusz, H. Spiering, P. Gütlich, J. Appl. Crystallogr. 2000, 33, 201-205; c) J. Kusz, H. Spiering, P. Gütlich, J. Appl. Crystallogr. 2001, 34, 229-238; d) J. Kusz, D. Schollmeyer, H. Spiering, P. Gütlich, J. Appl. Crystallogr. 2005, 38, 528-536; e) M. Marchivie, P. Guionneau, J. A. K. Howard, G. Chastanet, J.-F. Létard, A. E. Goeta, D. Chasseau, J. Am. Chem. Soc. 2002, 124, 194-195; f) A. L. Thompson, A. E. Goeta, J. A. Real, A. Galet, M. C. Muñoz. Chem. Commun. 2004, 1390-1391; g) V. Niel, A. L. Thompson, A. E. Goeta, C. Enachescu, A. Hauser, A. Galet, M. C. Muñoz, J. A. Real, Chem. Eur. J. 2005, 11, 2047-2060; h) K. Ichiyanagi, J. Hebert, L. Toupet, H. Cailleau, P. Guionneau, J.-F. Létard, E. Collet, Phys. Rev. B 2006, 73, 060408(R); i) V. A. Money, I. R. Evans, M. A. Halcow, A. E. Goeta, J. A. K. Howard, Chem. Commun. 2003, 158-159; j) V. A. Money, J. Elhaïk, M. A. Halcow, J. A. K. Howard, Dalton Trans. 2004, 1516-1518; k) E. J. MacLean, C. M. McGrath, C. J. O'Connor, C. Sangregorio, J. M. W. Seddon, E. Sinn, ; F. E. Sowrey, S. J. Teat, A. E. Terry, G. B. M. Vaughan, N. A. Young, Chem. Eur. J. 2003, 9, 5314-5322; F. E. Sowrey, S. J. Teat, A. E. Terry, G. B. M. Vaughan, N. A. Young, Chem. Eur. J. 2003, 9, 5314-5322; 1) V. Legrand, S. Pillet, H.-P. Weber, M. Souhassou, J.-F. Létard, P. Guionneau, C. Lecomte, J. Appl. Crystallogr. 2007, 40, 1076-1088; m) E.
Trzop, M. Buron-Le Cointe, H. Cailleau, L. Toupet, G. Molnar, A Bousseksou, A. B. Gaspar, J. A. Real, E. Collet, J. Appl. Crystallogr. 2007, 40, 158-164; n) V. Legrand, S. Pillet, C. Carbonera, M. Souhassou, J.-F. Létard, P. Guionneau, C. Lecomte, Eur. J. Inorg. Chem. 2007, 5693-5706.

[9] M. Marchivie, P. Guionneau, J.-F. Létard, D. Chasseau, Acta Cryst. B 2005, 61, 25-28.

[10] a) J.-F. Létard, J. Mater. Chem., 2006, 16, 2550-2559; b) J.-F. Létard, P. Guionneau, O. Nguyen, J. S. Costa, S. Marcén, G. Chastanet, M. Marchivie, L. Goux-Capes, Chem. Eur. J. 2005, 11, 4582-4589.

[11] a) J. A. Real, A. B. Gaspar, M. C. Muñoz, Dalton Trans. 2005, 2062 2079; b) P. Gütlich, A. Hauser, H. Spiering, Angew. Chem. 1994 106, 2109-2141; Angew. Chem. Int. Ed. Engl. 1994, 33, 2024-2054.

[12] J. A. Real, A. B. Gaspara, V. Niel, M. C. Muñoz, Coord. Chem. Rev. 2003, 236, 121-141.

[13] J.-F. Létard, G. Chastanet, O. Nguyen, S. Marcen, M. Marchivie, P. Guionneau, D. Chasseau, P. Gütlich, Monatsh. Chem. 2003, 134 , $165-182$.

[14] A. Ozarowski, B. R. McGarvey, A. B. Sarkar, J. E. Drake, Inorg. Chem. 1988, 27, 628-635.

[15] S. M. Neville, B. A. Leita, G. J. Halder, C. J. Kepert, B. Moubaraki, J.-F. Létard, K. S. Murray, Early View, Chem. Eur. J. 2008.

[16] a) N. Moliner, M. C. Muñoz, S. Létard, J.-F. Létard, X. Solans, R. Burriel, M. Castro, O. Kahn, J. A. Real, Inorg. Chim. Acta 1999, 291, 279-288; b) A. B. Gaspar, M. C. Muñoz, N. Moliner, V. Ksenofontov, G. Levchenko, P. Gütlich, J. A. Real, Monatsh. Chem. 2003 , 134, 285-294.

[17] G. Dupouy, M. Marchivie, S. Triki, J.-Y. Salaun, J. Sala-Pala, C. J. Gomez-García, P. Guionneau, Inorg. Chem. 2008, 47, 8921-8931.

[18] D. L. Reger, J. R. Gardinier, M. D. Smith, A. M. Shahin, G. J. Long, L. Rebbouh, F. Grandjean, Inorg. Chem. 2005, 44, 1852-1866.

[19] G. S. Matouzenko, A. Bousseksou, S. Lecocq, P. J. van Koningsbruggen, M. Perrin, O. Kahn, A. Collet, Inorg. Chem. 1997, 36, 58695879.

[20] a) C. F. Sheu, S. Pillet, Y. C. Lin, S. M. Chen, I. J. Hsu, C. Lecomte, Y. Wang, Inorg. Chem. 2008, 47, 10866-10874; b) S. Pillet, C. Lecomte, C. F. Sheu, Y. C. Lin, I. J. Hsu, Y. Wang, J. Pharm. Technol. J. Phys. Conference Series 2005, 21, 221-226.

[21] W. Vreugdenhil, J. H. van Diemen, R. A. G. de Graaff, J. G. Haasnoot, J. Reedijk, A. M. van der Kraan, O. Kahn, J. Zarembowitch, Polyhedron 1990, 9, 2971-2979.

[22] V. Niel, A. B. Gaspar, M. C. Muñoz, B. Abarca, R. Ballesteros, J. A. Real, Inorg. Chem. 2003, 42, 4782-4788.

[23] P. Guionneau, M. Marchivie, G. Bravic, J.-F. Létard, D. Chasseau, Top. Curr. Chem. 2004, 234, 97-128.

[24] a) P. Guionneau, M. Marchivie, G. Bravic, J.-F. Létard, D. Chasseau, J. Mater. Chem. 2002. 12, 2546-2551; b) P. Guionneau, C. Brigouleix, Y. Barrans, A. E. Goeta, J.-F. Létard, J. A. K. Howard, J. Gaultier, D. Chasseau, C. R. Acad. Sci., Ser. IIc: Chim. 2001, 4, 161-171; c) M. G. B. Drew, C. J. Harding, V. McKee, G. G. Morgan, J. Nelson, J. Chem. Soc. Chem. Commun. 1995, 1035-1038.

[25] a) V. Briois, C. Cartier dit Moulin, P. Sainctavit, C. Brouder, A.-M. Flank, J. Am. Chem. Soc. 1995, 117, 1019-1026; b) C. Cartier dit Moulin, P. Rudolf, A.-M. Flank, C. T. Chen, J. Phys. Chem. 1992, 96, 6196-6198; c) D. Collison, C. D. Garner, C. M. McGrath, J. F. W. Mosselmans, M. D. Roper, J. M. W. Seddon, E. Sinn, N. A. Young, J. Chem. Soc. Dalton Trans. 1997, 4371-4376; d) J. A. Real, I. Castro, A. Bousseksou, M. Verdaguer, R. Burriel, M. Castro, J. Linares, F. Varret, Inorg. Chem. 1997, 36, 455-464; e) K. Okamoto, K. Nagai, J. Miyawaki, H. Kondoh, T. Ohta, Chem. Phys. Lett. 2003, 371, 707712; f) M. Khalil, M. A. Marcus, A. L. Smeigh, J. K. McCusker, H. H. W. Chong, R. W. Schoenlein, J. Phys. Chem. A 2006, 110, $38-$ 44; g) H. Oyanagia, T. Tayagakib, K. Tanaka, J. Phys. Chem. Solids 2004, 65, 1485-1489.

[26] J. J. Lee, H. S. Sheu, C. R. Lee, J. M. Chen, J. F. Lee, C. C. Wang, C. H. Huang, Y. Wang, J. Am. Chem. Soc. 2000, 122, 5742-5747.

[27] a) R. H. Herber, Inorg. Chem. 1987, 26, 173-178; b) D. C. Figg, R. H. Herber, J. A. Potenza, Inorg. Chem. 1992, 31, 2111-2117; c) P. Weinberger, M. Grunert, Vib. Spectrosc. 2004, 3, 175-186; d) C. L. 
Zilverentant, G. A. van Albada, A. Bousseksou, J. G. Haasnoot, J. Reedijk, Inorg. Chim. Acta 2000, 303, 287-290; e) K. L. Ronayne, H. Paulsen, A. Höfer, A. C. Dennis, J. A. Wolny, A. I. Chumakov, V. Schünemann, H. Winkler, H. Spiering, A. Bousseksou, P. Gütlich, A. X. Trautwein, J. J. McGarvey, Phys. Chem. Chem. Phys. 2006, 8, 4685-4693.

[28] S. Hayami, R. Kawajiri, G. Juhàsz, T. Kawahara, K. Hashiguchi, O. Sato, K. Inoue, Y. Maeda, Bull. Chem. Soc. Jpn. 2003, 76, 12071213.

[29] a) L. P. Battaglia, M. Carcelli, F. Ferraro, L. Mavilla, G. Pellizzi, J. Chem. Soc. Dalton Trans. 1994, 2651-2654; b) B. Abarca, R. Ballesteros, M. Elmasnaouy, Tetrahedron 1998, 54, 15287-15292.
[30] Z. Otwinowski, W. Minor, Methods Enzymol. 1997, 276, 307-326.

[31] SAINTPLUS, Bruker Analytical X-Ray System, Inc., Madison, WI 1997-1998.

[32] G. M. Sheldrick, SADABS, Version 2.03, University of Göttingen, Germany, 2002.

[33] G. M. Sheldrick, SHELXS97, Program for Structure Solution, University of Göttingen, Germany, 1997.

[34] G. M. Sheldrick, SHELXL97, Program for Structure Refinement, University of Göttingen, Germany, 1997.

Received: November 4, 2008 Published online: January 13, 2009 